\title{
Consumer Rights, Consumer Protection and Public Policy in Nigeria: A Critical Review
}

\author{
Ebitu, Ezekiel Tom ${ }^{1}$ \\ ${ }^{1}$ Department of Marketing, University of Calabar, Calabar, Nigeria \\ Correspondence: Ebitu, Ezekiel Tom, Ph. D, Department of Marketing, University of Calabar, Calabar, Nigeria. \\ Tel: 234-803-945-1333. E-mail: edidiongebitu@yahoo.com
}

Received: September 22, 2014

Accepted: October 24, 2014

Online Published: November 25, 2014

doi:10.5539/ibr.v7n12p120

URL: http://dx.doi.org/10.5539/ibr.v7n12p120

\begin{abstract}
Consumer's rights are inalienable rights that must be protected by the consumer, business organizations and the government Public policies emanate from the government of a state and are geared towards regulating business relationships among the citizenry or distributing social amenities to individuals and communities. The operation of business demands sound public policies and laws aimed at promoting harmony, stability and growth in the economy. Consumer rights and protection laws are essential in Nigeria to check and regulate the excesses of businesses and individuals against the Nigerian consumer. Government has established specific agencies to monitor, identify and prosecute fraudulent businessmen and women. This work therefore assesses the impact of public policy vis-à-vis consumer protection in Nigeria and recommends that much still need to be done.
\end{abstract}

Keywords: consumer rights, consumer protection, public policy and Nigeria

\section{Conceptual Framework}

Policies constitute the framework, the lever, the plank, and the backbone for meaningful decisions. Policy is defined as "a verbal, written or implied overall guide setting up boundaries that supply the general limits and direction in which managerial action will take place" (Awujo 1997, p. 61). They are planned expressions of a group's official attitude towards the range of behavior within which it will permit or desire people to act. Policies define how people should react to situations, which occur frequently without having to wait to be told what to do. Gordon (1986, p. 445) refers to public policies "as the organizing framework of purposes and rationales for government programs that deal with specific societal problems". Etuk (2008, p. 24) quoting Musselman and Hughes $(1966$, p. 3) opines that public policy is the community conscience in the form of a statement, or interpretation of a statement, that carries with it the weight of government to matters of public morals, welfare, safety or public health. Most public policies are made to address major social and economic issues. Policies are an effort at coordinating and promoting uniformity in the conduct of government business and the behavior of its citizens.

Public policy has to do with those policies emanating from the government of a state or its agencies as opposed to private policies, which are from the private sector. They are either meant to regulate relationships among the citizens or distribute social amenities to individuals and communities. Public policies evolve as a result of public opinion and criticisms or that the policy makers are people-oriented and forward looking in developing policies to deliver results that conform to public interest. According to Ogunna $(1999$, p. 5) "in a responsible democratic government, public officials are under political obligation to be responsive and sensitive to the public opinion and criticisms which tend to influence their activities". The electronic and print media also constitute viable source for public opinion and criticism about the activities of public officers. Public policies may evolve from the Legislative, the Executive, the Judiciary or their operating agencies. A good public policy has the following characteristics and functions.

- It addresses the social and economic problems of the people by taking into consideration the various public opinions and criticisms.

- They serve as plans for promoting peace and harmony.

- Policies serve to direct future actions and are important in achieving coordination, economizing and public image 
- Good public policies coordinate the efforts of citizens so that they work as a team rather than at cross-purpose.

- $\quad$ Good public policies are people-friendly, responsive and sensitive, not nebulous and are aimed at achieving the overall good for the citizenry.

- Good public policies should be developed to answer public questions in advance and act as a means by which the societal objectives are achieved (Ebitu, 2008; p. 15).

In most cases, public policies are written because they are subjects of controversies and frequent communication between government officials and the people. Written policies make for equitable and constant treatment of problems.

The public policy process involves all the demands, pressures, conflicts, negotiations and compromises and formal and informal decisions that result in given policies being adopted (Hale, 1988) and pursued through actions of government. Thus, the policy process is not a smoothly functioning, ongoing sequence where one phase predictably follows another. It responds rather to pressures placed upon it at many points along the way, so that policy usually reflects the influence of diverse political focus (Gordon, 1986; p. 449). Public policies may evolve from Legislative, the executive, the judiciary or their operating agencies. There are various ways of looking at public policies. Some authors divide public policies into flexible and rigid, regulatory and distributive, or organizational, functional and societal but this paper shall adopt the categorization of Anderson (1984, pp. 113-116) as quoted by Eboh (1999, p. 77) into distributive, regulatory, self-regulatory and re-distributive, public policies.

The distributive type involves government's attempt to extend certain benefits to some individuals or groups in the society who are in dire need of them. For instance government effort towards solving the problems of unemployment and provision of loan facilities to business organizations and farmers through banks and government agencies may be grouped under distributive policy. Regulatory policies impose restraints on institutions, organizations and even individuals. Such policies could range from environmental pollution and sanitation, consumer protection to degree of foreign participation in business activities in Nigeria. It could also cover other institutions like advertising policies and practices. The self-regulated type, as the name implies is the type of regulation that has the support and endorsement of the regulated body or group for the promotion and protection of its members. For example, most professionals like Public Relations, Advertising, Law, Medicine, Engineering, etc. require that members should register and be licensed before they practice and that they abide by the code of ethics of such associations. The professions conduct and relations of members are regulated and; this helps the professional bodies check infiltration by quacks. The re-distributive type involves government's efforts to balance the allocation and distribution of wealth and other resources among the different strata of society. The Value Added Tax (VAT), Education Tax and other forms of taxation in Nigeria come under this type of policy. Most public policies are both distributive and regulatory in nature. Good governances are evolved to distribute resources to its citizens and regulate the manufacture, pricing, distribution, sales, and consumption of certain goods, drugs, services and ideas. As we go on, government's efforts in this direction shall be x-rayed.

\section{Consumerism and Consumer Rights}

Consumerism is the latest development in consumer awareness of, and insistence on, their rights as consumers' lack of satisfaction from the use of goods and services breeds grievances, frustration and criticisms from consumers thereby giving rise to consumerism. Consumerism has been defined by different authorities:

$>$ Agbonifoh, Ogwo and Nnolim (2007) see consumerism as the organized efforts of consumers aimed at promoting, protecting and enforcing the rights of consumers in their exchange relationships with all organization and individuals.

$>\quad$ Ibeh $(1999$, p. 306) defines consumerism as an organized effort of concerned citizens, business and government to equate the balance of power between parties to an exchange and redress and remedy injustices done to the consumers in the pursuit of a standard living.

Consumerism as an organized effort is relatively new in Nigeria. Most of the protections have come from government. Our traditional societies frowned at false measurements, abnormal pricing and selling of fake or adulterated goods. Such acts were always visited with severe sanctions. In the words of Ogbe (2001, p. 2) "Today, millions of Nigerians suffer from the consumption of adulterated goods, defective products and expired food items and drugs. The total effect of all these to our people are injuries, losses and damages. Our people suffer ill-health and discomfort brought on them as a result of consumption of expired or adulterated drugs and food items...finding foreign bodies and contaminants in our drinks seems to be on the increase". Despite the above 
picture, organized actions of individuals, groups and governments to protect the interest of Nigerian consumer have been halfhearted and hence less productive until today. Some traces of consumer activities have been noticed in different parts of Nigeria. A consumer movement called the Consumer Protection Association of Nigeria (CPAN) was formed in 1980 with the objectives of:

1) Promoting and stimulating consumers' interest and awareness in the goods and services they buy;

2) Ensuring that goods and services sold to consumers are merchantable and of the right quality;

3) Providing a better forum for dialogue between consumers, the government, manufacturers and middlemen;

4) Co-operating with the government and associations so that the interests of consumers could be better served, and

5) Serving as a clearing house for consumer complaints and assisting them to seek redress where there are disputes regarding goods and services purchased.

There exist other consumer associations such as Tenant association, the Consumers Association in Lagos, the Enugu Consumer Movement, and the Consumer's Club of Agwu. According to Agbonifoh and others (2007) "not only have their activities been restricted to their local bases but they have not embarked on nor received adequate publicity". The tempo of consumerism in Nigeria is still very low because of low level of literacy, the seller's market structure, absence of concerned citizens to lead or sponsor a consumer awareness campaign, and mass poverty. In recent times, there has been an increase in awareness of consumers, high incomes and changing but favorable legal and political scene. Therefore it is not surprising that much of the consumerist activities that have taken place in Nigeria originated from University students, Academic Staff Union of Universities (ASUU), Trade Unions, unemployed graduates and city dwellers.

Perspectives of Consumers Rights: Right is defined by the Black's law dictionary as "a power, privilege or immunity guaranteed under a constitution, statute or decisional laws or claimed as a respect of long usage". The Supreme Court of Nigeria in Afolayan V. Ogurinde (1990) NWLR (p. 127), P. 369 held that the right is an interest recognized and protected by law and that every right involves a three-fold relation in which the owner of it stands, viz:

- It is a right against some person or persons.

- It is a right to some act or omission of such person or persons.

- It is a right over or to something to which the act or omission relates.

Augie (1993, p. 236) opines that rights are things we can assert, demand or stand upon. They impose strict obligations upon others, obligations we often feel people should be made to perform and whose non-performance occasions feelings of resentment or indignation rather than mere disappointment. Consumer rights are those demands, claims, privileges or immunities, which the society recognizes as proper for consumers to enjoy in relations to goods, services, environment, development, information, education and redress. They are either imposed by law or accepted as a respect of long usage. Consumer right is a concept that imposes a duty on individuals, groups and institutions to act at all times to secure the well-being and satisfaction of consumers. The respect and recognition accorded these rights will help mankind attain a peaceful and egalitarian society.

The consumer has defined rights as far as the market-place is concerned. In his message to the American Congress in 1962, the President John F. Kennedy listed four rights which have come to be known as the Consumers' Bill of Rights; they include; the right to safety, the right to choose, the right to be heard, and the right to be informed others have also suggested such rights as the enhancement of the quality of life through physical environment, protection, safety and health, register their satisfaction and reasonable standard of nutrition and clothing. The United Nations has attached much importance to consumer rights that on April 9 1985, the General Assembly adopted specified guidelines on consumer protection which include:

1) Physical safety;

2) Promotion and protection of consumer economic interest;

3) Standard of quality and safety of consumer goods and services;

4) Distribution facilities for essential consumer goods and services;

5) Measures enabling consumers to obtain redress;

6) Education and information programs;

7) Advancing consumer interest, particularly in developing countries; 
8) International cooperation between government on regional and sub-regional basis.

In line with the UN, the International Organization of Consumer Union (IOCU) in 1983 approved eight basic rights that consumers worldwide are expected to enjoy. These are the rights to: basic needs, safety, a healthy environment, not to be exploited, redress, consumer education, be informed and be heard. Participants from various ECOWAS countries in July 1992 in Dakar, Senegal noted with absolute dismay that nearly a decade after the adoption of the UN guidelines on consumer protection, the implementation in the African continent has been a far cry from reality (Ebitu, 1995; p. 51). In Nigeria the typical consumer has constantly been deprived and robbed of these rights. Bamboye (2002, p. 39) has identified the following consumer complaints concerning marketing activities in Nigeria

a) Charging higher prices than necessary. They often thought that the causes of these higher prices are high distribution costs, high advertising and promotional costs, and excessive mark ups.

b) Unsafe products: consumer's criticism is that products lack the quality they should have. These are complaints as to 'original' and 'Taiwan' products, and that products deliver little benefits

c) Deceptive practices that lead consumers to believe that they will get more value than they actually do, for example, exaggerating product contents through subtle design or not filling the package to the top.

d) Designing products to become obsolete before they should actually need to be replaced.

e) Higher pressure selling, that is, persuading people to buy products and services they have no intention to buy.

Nwankwo (1985, p. 26) captures the deteriorating consumer status in Nigeria thus; "today locally manufactured products have become synonymous with poor quality, locally assembled plants are but shadows of their overseas parent stock, locally produced fabrics do not stand the first wash, shoes lose the soles after first use in the rains, expired drugs are hawked with impunity, shoddy products proliferated and sold with reckless abandon, prices rigged and consumers exploited. Some manufacturers even put labels on products, which claim to be otherwise. For the Nigerian consumer, the litany of woes is endless". These statements are still relevant today. In fact the Nigerian consumer is akin to a toothless bulldog who is bombarded with some products which by omission or commission are not fit for consumption.

\section{Public Policy and Consumer Protection Strategies}

Government policy as touching the consumer is meant to redistribute wealth and also regulate and check the excesses of businesses and individuals against the Nigerian consumer. Other reasons aimed at protecting the consumer include:

- $\quad$ To ensure that fake products are not sold to consumers;

- To guard against false and misleading advertisements;

- $\quad$ To protect consumers from consuming dangerous drugs and polluted goods;

- To ensure that goods are manufactured based on approved standards thereby preventing the marketing of inferior and adulterated products and drugs to consumers;

- To avoid cheating consumers with regards to credit sales;

- Since most consumers are illiterates, consumer protection ensures that producers and sellers respect the rights of consumers in the market place;

- To ensure that consumers get value for their money and maintain a suitable standard of living.

A better appreciation of government role can be gained by considering separately the numerous consumer protection laws and other consumer oriented actions and pronouncements.

\subsection{The Criminal Code}

The criminal code at section 245 prohibits the corruption of water sources and places imprisonment of six months on culprits and section 247 warns against pollution of atmosphere or doing any act "likely to spread the infection of any disease dangerous to life, whether human or animal". The culprit is also guilty of a misdemeanor, and is liable to imprisonment for six months. As far back as 1915, the Water Works Act had prohibited the introduction of any obnoxious or injurious matter in the water works, public fountains, streams etc. and a fine of 20 pounds, was placed (Adewale, 1994; p. 158). The criminal code and other laws were established long before now to take care of the citizens who incidentally are the consumers in the economy of any nation. 


\subsection{The Sales of Goods Act (1893)}

Some of its more important provisions include the seller must have the right/title to sell the goods at the time of sale, the goods should be free from encumbrances; the goods must be of merchantable quality. When goods are sold by description or sample, such goods must conform to that description or sample in quality. Also goods must fulfill the purpose which was disclosed to the buyer at the time of sale otherwise, the seller will be liable. The rule 'caveat emptor' meaning "let the buyer beware" does not apply anymore because there may be inherent defects in the product and nobody ordinarily can detect until usage. Moreover, the interest of the consumer buyer is now paramount as the emphasis now is on customer satisfaction and protection.

\subsection{Food and Drugs Act (1974)}

The body charged with enforcing this law is known as the Food and Drug Administration. The Act prohibits the sale of any Food or Drug that has poisonous or harmful substance and/or is unfit for human consumption, and was manufactured, prepared, preserved, packaged or stored under unsanitary conditions. Sections 2,5 and 11 warns against advertisement or information or publication likely to mislead or create a wrong impression about products, drugs, cosmetics, devise as to its quality, character, value composition merit or safety. Section 17 deals with penalties for offenders: two years imprisonment or $\$ 1,000.00$ or both. According to Ebitu (2002, p. 112), these sanctions are still heavy punishment for offenders today although the monetary aspects needs upward review.

\subsection{Weight and Measures Act (1974)}

This law directs on the appropriate use of measurement in terms of length, area, volume, capacity, mass or weight for purposes of protecting the consumer in particular and others in the business transaction. It is an offence for any person to willfully defraud another through the use of any weight, measure, weighting and measurement instruments. The Act also provides against the sale of any packaged goods whose minimum net weight is not clearly stated on a label securely attached to it.

\subsection{Standard Organization of Nigeria Act (SON) 1989}

It was established among other things to organize and do everything necessary to ensure compliance with standards designated and approved by council, undertake investigations necessary into quality of facilities and products manufactured and imported into the country so as to establish a quality assurance system, including certification of factories, products and laboratories and to cooperate with corresponding national or intentional organizations in such fields of activities as it considers necessary with a view to securing uniformity in standards specifications. SON has been criticized of not doing its work well, although Ekerete (2000) reports that in 1991 alone the organization seized 26 containers of imported products that was of extremely poor quality. SON's Annual Report 1997 showed that the following products found to be hazardous to life and health were impounded, seized and subsequently destroyed: two containers of tungsten filaments lamps, two containers of used tyros, one container of electric cables, one container of electric pressing irons and two containers of biscuits. In the same year the SON bulletin reported that the organization handled 13 consumer complaints as against 28 in 1996. In some cases, investigations were concluded while compensation were paid by concerned suppliers to complainants were actions and investigation were concluded (Ezinwo, 2003; p. 22). In recent years not much is heard about this body; it should sit up.

\subsection{Advertising Practitioners (Registration, Etc.) Act (1988)}

Regulates and defines who is qualified to practice advertising. It also sets guidelines for registration of advertisers and punishment of quacks. There are other laws and agencies that regulate advertisements. They include Food and Drugs Act (1974), Central Bank of Nigeria Act (CBN), NAFDAC, Tobacco Smoking (Control, etc.) Act 1990, SON, Marketing (Breast Milk Substitutes) Acts 1990, etc.

\subsection{Federal Environmental Protection Agency (1992)}

This agency was established to maintain good environmental quality by asking companies dealing directly with the environment to conduct an Environmental Impact Assessment (EIA) of their activities in order to control and measure the extent of degradation and pollution that may occur as a result of their projects.

\subsection{Consumer Protection Council Act 1992}

Before now there had existed the consumer education and protection council of 1970 . We cannot substantiate about the achievement or viability of this council until 1992 when the consumer protection council act was enacted. The functions of this council include:

a) Provide speedy redress to customers complaints through negotiations, meditations and conciliation; 
b) Seek ways and means of removing or eliminating from the market hazardous products and causing offenders to replace such products with safer and more appropriate alternatives;

c) Publish form time to time, list of products whose consumption and sale have been banned, withdrawn, severally restricted or not approved by the Federal Government or foreign governments;

d) Cause an offending company, firm, trade association or individual to protect, compensate, provide relief and safeguards to injured consumers or communities from adverse effects of technologies that are inherently harmful, injurious, violent or highly hazardous;

e) Organize and undertake campaigns and other forms of activities that will lead to increased public consumer awareness;

f) Encourage trade, industry and professional associations to develop and enforce in their various fields quality standards designed to safeguard the interest of consumers;

g) Issue guidelines to manufacturers, importers, dealers and wholesalers in relation to their obligation under this Decree;

h) Encourage the information of voluntary consumer groups or associations for consumers' wellbeing among other functions.

Offences are created under the Act and contravention attracts a fine of N50,000 or five years imprisonment or both. Apart from publishing consumer protection leaflet which states the responsibilities of the consumer and attending few conferences on consumer protection, Ezinwo (2003.40) reports that the council's impact is yet to be felt in Nigeria.

\subsection{National Agency for Food, Drugs Administration and Control (NAFDAC)}

It was established in 1993 to perform the following functions among others:

a) Regulate and control the importation, exportation, manufacture, advertisement, distribution, sales and use of food, drugs, cosmetics, medical devices, bottled water and chemicals.

b) Conduct appropriate tests and ensure compliance with standard specifications designated and approved by the council for the effective control of the quality of food, drugs, cosmetics, medical devices, bottled water and chemicals and their raw materials as well as their production processes in factories and other establishment.

c) Undertake appropriate investigations into the production premises and raw materials for food, drugs, cosmetics, medical devices, bottled water and chemical and establish relevant quality assurance systems, including certification of the production sites and of the regulated products.

d) Compile standard specifications and guidelines for the production, importation, exportation, sales and distribution of food, drugs, cosmetics, medical devices, bottled water and chemicals.

e) Undertake the registration of food, drugs, cosmetics, medical devices, bottled water and chemicals.

f) Control the exportation and issue quality certification of food, drugs, cosmetics, medical devices, bottled water and chemicals intended for export.

g) Establish and maintain relevant laboratories or other institutions in strategic areas of Nigeria as may be necessary for the performance of its function under this Decree.

Since the agency came on stream, it has been recording measure of success, educating the public, registering both locally manufactured and imported products and sanctioning producers and sellers of unregistered, and illegal products in Nigeria. The Agency has done so much to bring sanity to drugs and imported/manufactured foods in Nigeria. Billions of naira worth of food items considered not fit for consumption have been seized and destroyed. In May 2004, the Agency saved the nation from imminent catastrophe from Indomie poison. Fake toothpastes worth $\$ 10$ m were seized at Onne Port in Rivers State. In 2007, the Onitsha drug market was closed down to ensure that fake drugs are sorted out and destroyed, although the market was reopened after sanitization. Anyanwu (2007, p. 6) reports that Onitsha-head market was closed down on March 6, 2007 over fake and counterfeit drugs. After screening of the market, NAFDAC removed and publicly destroyed truckloads of fake, counterfeit, expired, banned and smuggled drugs worth over N6.5bn from the market. The traders later promised never to deal on fake drugs any longer. The agency and its officials have been honored with so many prizes because of their commitment and dedication to duty.

Other laws that protect the consumer either against misleading advertising, adulterated, counterfeit and fake 
drugs, foods, cosmetics and bottled water, or unnecessary price increases are available in our law books. Some of them include the Tobacco Smoking (Control )Amendment Act 2002 which prohibits smoking in public places and offenders are liable to a fine of $\mathrm{N} 20,000.00$ for individuals and $\$ 100,000.00$ for organizations; National Drug Law Enforcement Agency (NDLEA) noted that those dealing on fake drugs are liable on conviction to 15 years imprisonment or a fine of $\$ 500,000.00$; the Productivity, Price and Income Board Act (1997) which regulates price adjustments; the Rent Control Act, which regulates the relationship of landlords with tenants and protects the tenants against shylock landlords; the Hire Purchase Act, the Trade Marks Act and so on. All these laws are aimed at protecting the consumer but the problem is that of enforcement by those charged with implementing the laws. Anyanwu and Onuoha (1999, p. 320), Ekerete (2000, p. 195), and Ezinwo (2003) all agree that a lot still remain to be done by government. These are in the areas of consumer education, creating awareness and actually enforcing the present laws, which are more than enough to protect the consumer if effectively implemented.

Apart from the use of law, the Nigerian government sometimes creates awareness on consumer issues: Government also uses moral suasion to appeal to the conscience of businesses to be responsible, and for the consumers to be alert to what they buy and consume. For instance, the Nigerian Customs runs a TV program every Monday which persuades Nigerians to avoid smuggling, stop importing banned products and not to give or receive bribes. NAFDAC also mounts an advert: "Nigerians shine your eyes" which is mostly featured on Nigerian Television Authority network news to warn Nigerians to be careful buyers. The Nigerian press has done a lot in educating consumers and pointing out to the public the "wrong doings" of businesses and government. The press has waxed stronger, and more focused in its exploits to liberate the down-trodden consumers of this country. The Nigerian media is going to do more with the coming on board of the Freedom of information Act. (2011).

\section{Conclusion}

Government has recorded some remarkable achievements, by enacting various laws and formulating policies to regulate, protect and preserve consumer rights. The exploits of NAFDAC in recent times are highly commendable. The problem with the implementation of consumer right protection laws and policies is that those charged with this function sometimes become corrupt, heavy-footed, and cash trapped to perform their jobs and/or subject to frequent changes to compensate political supporters who may not know anything as far as their appointments and positions are concerned. It is hoped that government will move away from the point of law making (legality) to the point of making consumers actually enjoy the contents of the law (legitimacy). Consumers too need serious education while the economy needs to be productive and consumer-friendly.

\section{References}

Aaker, D. A., \& Day, G. S. (1976). Consumer: Search for Consumer Interest. New York: Free Press.

Adewale, B. (1994). Customary Environmental Law and Sustainable Development. NIALS.

Afolayan, V. O. (1990). NWLR (Pt. 127), P. 36690.

Agbonifoh, B. A., Ogwo, O. E., \& Nnolim, D. A. (2007). Marketing in Nigeria: Concept, Principles and Decisions. Aba: Afrtowers LTD Publishers.

Anderson, J. E. (1984). Public Policy Making (3rd ed.). New York: Holt, Renehart and Winston.

Anyanwu, G. (2007). Fake Drugs: NAFDAC Reopens Onitsha Drugs Market. Daily Sun, Wednesday, June 27.

Augie, A. N. (1993). Women Rights in Law and Practice: Social Welfare. In A. O. Obilade (Ed.), women in law. Faculty of Law University of Lagos.

Awujo, A. C. (1997). Elements of Management (2nd ed.). Owerri: Ollwersm Industrial Publishing House.

Bamgboye, E. D. (2002). Education and the Marketing Bill. This Day Newspaper, July 2002.

Black, H. C. (1990). Blacks' Law Dictiionary (6th ed.). Paul Minnesota: West Publishing Company.

Ebitu, E. T. (2002). Promotion Mananagement: Concepts and Strategies Calabar. Eddynoll Publishers.

Ebitu, E. T. (2008). Public Policy and Consumer Protection in Nigeria. Journal of Business and Social Sciences, $3(1), 14-26$.

Eboh, F. E. (1999). Public Sector Management. Enugu: Skinno Prints Nigeria.

Ekerete, P. P. (2000). Consumer Behaviour: Theory and Practice. Owerri: Springfield Publishers.

Etuk, E. J. (2008). Foundations of Modern Business Management. Calabar: Unical Press. 
Ezinwo, I. O. (2003). Consumer Rights Protection: The Case of Consumer in Rivers State. An MBA Thesis of the Rivers State University of Science and Technology, Port Harcourt, Nigeria.

Gordon, G. J. (1986). Public Administration in America (3rd ed.). New York: St. Martins Press.

Ibeh, K. I. N. (1999). Consumerism' in Introduction to Business Administration. Owerri: Avan Global Publishers.

Ndukwe, O. U. (2000). Elements of Nigerian Environmental Laws. Calabar: Unical Press.

Nwankwo. (1995). Consumerism: The Farce of Consumer Protection in Africa. An Unpublished Theisis Submitted to the Department of Marketing, University of Nigeria, Enugu Campus.

Oliver, G. (1980). Marketing Today. London: Prentice Hall International Inc.

\section{Copyrights}

Copyright for this article is retained by the author(s), with first publication rights granted to the journal.

This is an open-access article distributed under the terms and conditions of the Creative Commons Attribution license (http://creativecommons.org/licenses/by/3.0/). 